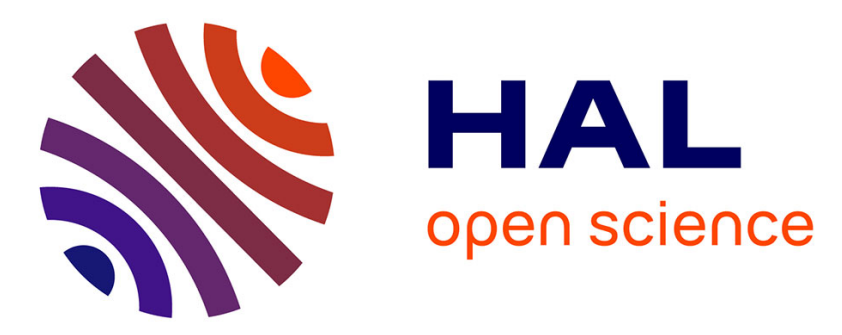

\title{
Electrophoretically mediated microanalysis for the evaluation of interspecies variation in cholinesterase metabolism
}

\author{
Ana Luísa Simplício, Joana Moura
}

\section{- To cite this version:}

Ana Luísa Simplício, Joana Moura. Electrophoretically mediated microanalysis for the evaluation of interspecies variation in cholinesterase metabolism. Electrophoresis, 2010, 31 (14), pp.2374. 10.1002/elps.200900769 . hal-00599458

\section{HAL Id: hal-00599458 https://hal.science/hal-00599458}

Submitted on 10 Jun 2011

HAL is a multi-disciplinary open access archive for the deposit and dissemination of scientific research documents, whether they are published or not. The documents may come from teaching and research institutions in France or abroad, or from public or private research centers.
L'archive ouverte pluridisciplinaire HAL, est destinée au dépôt et à la diffusion de documents scientifiques de niveau recherche, publiés ou non, émanant des établissements d'enseignement et de recherche français ou étrangers, des laboratoires publics ou privés. 
Electrophoretically mediated microanalysis for the evaluation of interspecies variation in cholinesterase metabolism

\begin{tabular}{|r|l|}
\hline Journal: & Electrophoresis \\
\hline Manuscript ID: & elps.200900769.R3 \\
\hline Wiley - Manuscript type: & Short Communication \\
\hline Date Submitted by the \\
Author: & 08-Mar-2010 \\
\hline Complete List of Authors: & $\begin{array}{l}\text { Simplício, Ana; IBET/ITQB-UNL } \\
\text { Moura, Joana; IBET/ITQB-UNL }\end{array}$ \\
\hline Keywords: & cholinesterases, in-capillary, EMMA \\
\hline
\end{tabular}

\section{s scholarONE \\ Manuscript Central}




\title{
Electrophoretically mediated microanalysis for the evaluation of interspecies variation in cholinesterase metabolism
}

Joana Moura and Ana Luisa Simplício

IBET/ ITQB-UNL, Av. da República - EAN, 2780-157 Oeiras, Portugal

\begin{abstract}
The present work describes an electrophoretically mediated microanalysis (EMMA) method, suitable for the pre-clinical evaluation of the hydrolysis of ester drugs by the serum of different animals and for further characterization of human-animal correlation. Dog, cat, cow, horse, sheep, rat and human serum were diluted (25\%) in the appropriate buffer and replaced the enzyme solution usually used in EMMA methods for the study of enzyme kinetics. They were then compared in terms of the ability to hydrolyse acetylthiocholine and butyrylthiocholine $(0.25 \mathrm{mM})$ by in capillary reaction. Human serum afforded the highest conversion rates (52\% butyryltiocholine and $34 \%$ acetylthiocholine) followed by horse $(31 \%, 35 \%), \operatorname{dog}(26 \%, 24 \%)$, cat $(22 \%, 14 \%)$, rat $(11 \%, 15 \%)$ and sheep $(8 \%, 8 \%)$. Hydrolysis by bovine serum was negligible.

The method is fast (under 8 minutes including rinsing steps), sensitive (under $25 \mu \mathrm{M}$ substrate could be quantified) and repeatable_( $\mathrm{RSD} \approx 2 \%)$, only requiring minute amounts of sample.
\end{abstract}

Deleted: while h 
Important differences have been observed in the activity of esterases in different mammals. Such differences must be considered when using pre-clinical species to optimize the pharmacokinetic properties of ester compounds intended for human use [1]. Due to ethical constraints, the use of animals in pre-clinical tests should be reduced and therefore miniaturized methods should be developed for minimizing the consumption of animal tissue. Moreover animal-human correlations should be better characterized.

Electrophoretically mediated microanalysis (EMMA) is a branch of capillary electrophoresis that presents several advantages in the study of enzyme activity. The method conjugates the potential of a separation technique with the convenience of on-

| line reaction, allowing simultaneous, unattended reaction and detection [2]. EMMA methods also have the advantages of low sample consumption and of avoiding interference by sample components that might absorb at the same wavelength as the substrate or product.

We have developed a fast EMMA method in the plug-plug mode, with the aim of evaluating the differences in the hydrolytic profile of acetyl and butyrylthiocholine by the serum of various animals. Commercial butyryl and acetylcholinesterases were used for the purpose of method development. The enzyme solutions were subsequently

| replaced by diluted serum samples and evaluated for substrate specificity_Analytical separations were carried out in a Beckman P/ACE MDQ capillary electrophoresis system coupled with diode array detector (DAD) (Palo Alto, CA, USA) and detection was at $230 \mathrm{~nm}$. The sample tray was kept at $10^{\circ} \mathrm{C}$ for sample preservation. Reaction and separation occurred in a silica capillary, $50 \mu \mathrm{m}$ i.d., and $42 \mathrm{~cm}$ length, at $37^{\circ} \mathrm{C}$. The capillary was rinsed daily with $\mathrm{NaOH} 0.1 \mathrm{M}(20 \mathrm{~min})$, water $(20 \mathrm{~min})$ and working buffer $(20 \mathrm{~min})$ at $5 \mathrm{psi}$. The same rinsing sequence $(2 \mathrm{~min})$ was performed before each run. The running buffer was as developed by other authors [3] and consisted of $30 \mathrm{mM}$ borate/phosphate at $\mathrm{pH} 8$, filtered with PVDF $0.45 \mu \mathrm{m}$. The plug-plug method was used with the following injection sequence: enzyme or serum solution, $0.2 \mathrm{psi}, 15 \mathrm{sec}$; substrate, $0.4 \mathrm{psi}, 60 \mathrm{sec}$; $1 \mathrm{kV}$ for $0.37 \mathrm{~min}$; waiting step, $0.6 \mathrm{~min}$; separation at $20 \mathrm{kV}$ for $1.6 \mathrm{~min}$.

Solutions of acetylcholinesterase (AChE, from electric eel) and butyrylcholinesterase (BChE, from horse serum, Sigma-Aldrich) were prepared at 0.1-0.5 U/ml in running buffer and used for method development. Solutions of acetylthiocholine and butyrylthiocholine iodide (Fluka) were prepared in water and contrary to what had been

| observed by Tang et. al., the addition of magnesium was not necessary Dog, cat, cow, horse, sheep, rat and human serum were used for the preparation of solutions containing $10-50 \%$ serum in running buffer.

| The ability of the method to discriminate hydrolysis by AChE and BChE was evaluated by testing both thiocholines with both commercial cholinesterases. As expected, A $\bar{C} \bar{C} \bar{E}$ was specific for acetylthiocholine and did not hydrolyze butyrylthiocholine. BChE was selective for butyryltiocholine but still hydrolyzed a small amount of acetylthiocholine (Figure 1).

The Michaelis constant $\left(\mathrm{K}_{\mathrm{m}}\right)$ was tentatively determined at different AchE concentrations $(0.1,0.2$ and $0.5 \mathrm{U} / \mathrm{ml})$ for the hydrolysis of acetylthiocholine $(0-0.5$ $\mathrm{mM}$, in order to check method performance. The plots represented in figure 2 were constructed using the product areas obtained in each case, considering that these areas correlate to the reaction rate [3]. The estimated $\mathrm{K}_{\mathrm{m}}$ of $\mathrm{AChE}$, was $0.078,0.076$ and 0.12
Deleted: there is a need of developing

Deleted: reducing

Deleted: thus

Deleted: II

Deleted: II

Deleted: The plug-plug method was used with the following injection

sequence: enzyme or serum solution, 0.2 psi, 15 sec; substrate, 0.4 psi, 60 sec.; 1 $\mathrm{kV}$ for $0.37 \mathrm{~min}$; waiting step, $0.6 \mathrm{~min}$; separation at $20 \mathrm{kV}$ for $1.6 \mathrm{~min}$.II

Deleted: different concentrations of

Deleted: by AchE (0-0.5 mM)

Deleted: was tentatively determined at different enzyme concentrations $(0.1,0.2$ and $0.5 \mathrm{U} / \mathrm{ml}$ )

Deleted: II 


\section{References}

[1] Berry, L. M., Wollenberg, L., Zhao, Z., Drug Metabolism Letters, 2009, 3(2), 70-77.

[2] Zhang, J; Hoogmartens, J., Schepdael, A., Electrophoresis, 2008, 29, 56-65.

[3] Tang, Z., Wang, Z.; Kang, J.; Electrophoresis, 2007, 28, 360-365.

[4] Milatovic, D., Radic, Z., Zivin, M., Dettbarn, W., Free Radical Biology \& Medicine, 2000, 28, 597-603.

$\mathrm{mM}$, for enzyme concentrations of $0.1,0.2$ and $0.5 \mathrm{U} / \mathrm{ml}$ respectively, which is in the range of the $\mathrm{K}_{\mathrm{m}}$ determined by other authors $(0.092 \mathrm{mM})$ [4].

The enzyme solutions were then replaced by animal serum diluted in running buffer at different concentrations in the range at 10,25 and $50 \%$. It was confirmed that the method is sensitive to concentration changes as demonstrated in figure 3 for horse Acetylthiocholine and butyrylthiocholine were converted to thiocholine in different percentages (Figure 4a) by the serum of each animal. No previous data was found relative to cholinesterase activity in serum of the test animals. However, the differences detected in ester metabolism by the serum of different species were mostly consistent with previous observations obtained with traditional methods for mammal plasma $[5,6]$ where the highest activities were found for human, horse and dog while the lowest were for sheep and cow. In the case of the horse and contrary to us, Tecles et al. found ther activity towards butyryl than acetylthiocholine.

( (a) $\mathrm{n}=4$ ) and avoided indirect detection as in the case of the Ellman's colorimetric method. When analysing serum from the same animal, both substrates' migration times were 2.0 With RSD under $1 \%$. The migration time of thiocholine was 2.2 minutes with RSD under $2 \%(\mathrm{n}=4)$. Different types of serum afforded larger differences in migration times (up to 12 seconds, figure 4b) denoting some matrix effect. However, the method can be applied in early stages of drug evaluation and has the additional advantages of allowing automation and only requiring small quantities of substrate and blood (total This approach might be useful for the establishment of in vivo- in vitro correlations, for interspecies metabolic evaluation which can subsequently be applied pre-clinically to pollutants.

The authors wish to thank Faculdade de Medicina Veterinária and Universidade Técnica de Lisboa, particularly to Dr. Paula Tilley, Dr. Rui Caldeira and Dr. George Stilwell for donating the serum samples.

The authors have no conflicts of interest. 
[5] Tecles, F., Cerón, J., Research in Veterinary Science, 2001, 70, 233-238.

[6] Li, B., Sedlacek, M., Manoharan, I., Boopathy, R., Duysen, E., Masson, P., Lockridge, O., Biochemical Pharmacology, 2005, 70(11), 1673-1684. 


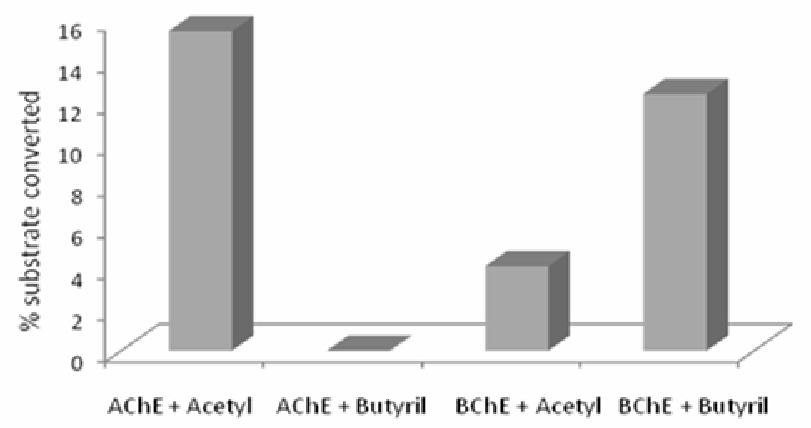

Figure 1: Conversion of thiocholines $(0.25 \mathrm{mM})$ by cholinesterases $(0.4 \mathrm{U} / \mathrm{ml})$. 


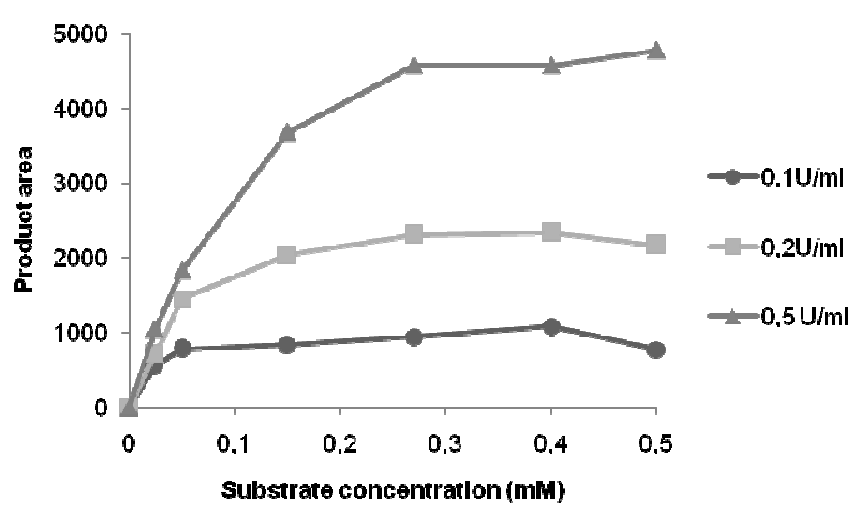

Figure 2: Michaelis-Menten plots for $\mathrm{AChE}$ at different substrate concentrations. 


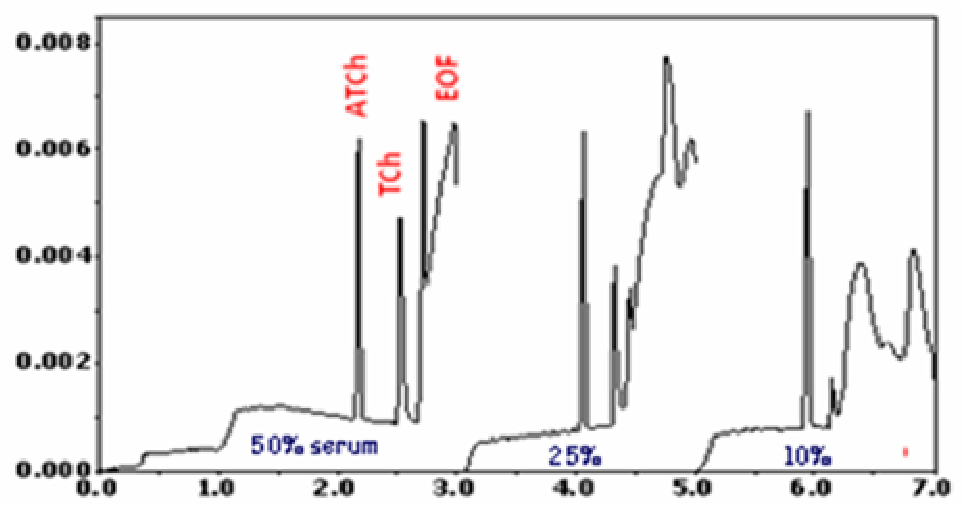

Figure 3: Hydrolysis of acetylthiocholine (ATch) to thiocholine (Tch) by horse serum at different concentrations. 


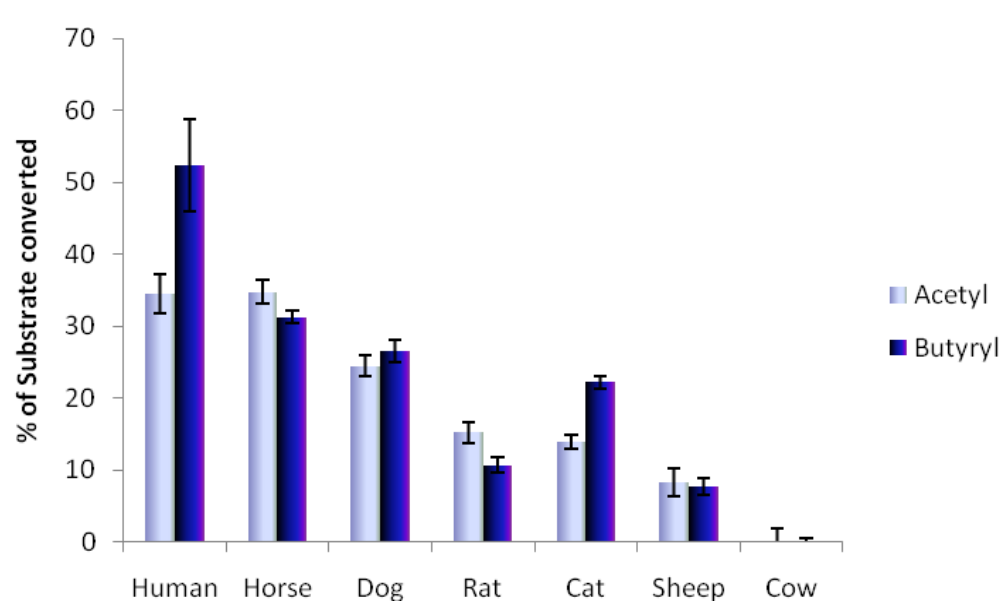

a)

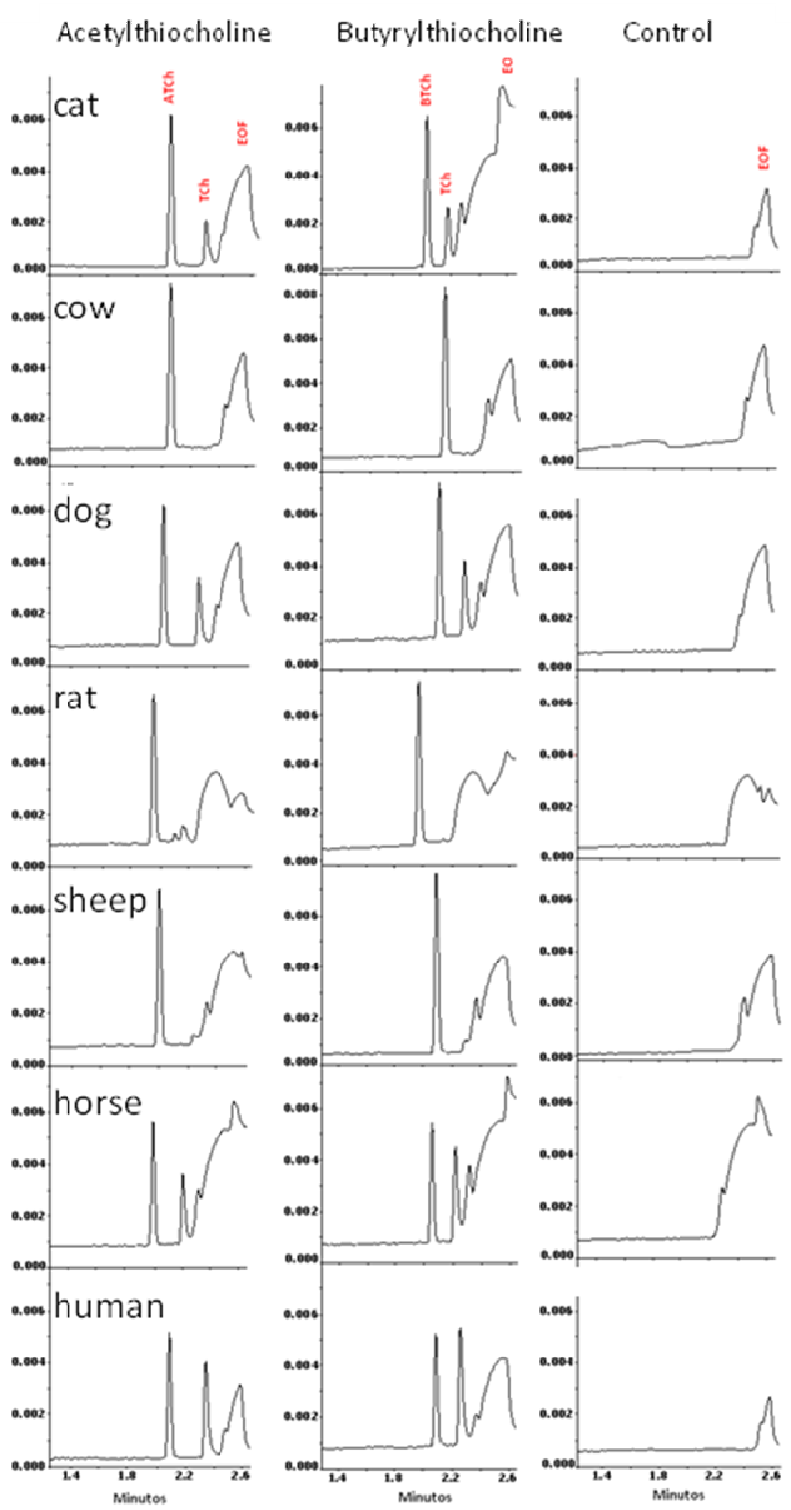

b)

Figure 4: a) Conversion of thiocholines $(0.25 \mathrm{mM})$ by the serum of different mammals (average of four replicates) at 25\%; b) Electropherograms obtained for each serum sample hydrolyzing acetylthiocholine (ATCh) or butyrylthiocholine (BTCh) to thiocholine (TCh). Controls consisted of analysis in the absence of any substrate. The wide peak observed in all samples corresponds to non charged species migrating with the electroosmotic flow (EOF) 
